TATАРІНОВ В. I., старший викладач кафедри цивільно-правових дисциплін (Дніпровський гуманітарний університет)

ДЕМІНОВА А. В., студент II курсу магістратури юридичного факультету (Дніпровський гуманітарний університет)

\title{
ПОНЯТТЯ, СУТНІСТЬ ТА ВИДИ ФУНКЦІЙ ЦИВІЛЬНОГО ПРАВА
}

У цивілістичній науці не склалося єдиного концептуального погляду на систему основних функцій цивільного права. Тому вивчення функцій цивільного права $є$ одним ыз найбільш важливих завдань сучасної цивілістичної науки. Не завжди предмет і метод цивільно-правового регулювання в сучасних умовах можуть бути визнані достатніми для вирішення питання галузевої приналежності тих чи інших суспільних відносин, що і актуалізує проблеми функцій цивільного права. У статті автори дослідили систему функцій цивільного права, розкрили поняття, їх сутність ы види.

Цінність функцій цивільного права можна побачити в розвитку суспільних відносин. Саме динаміка розвитку суспільних відносин може показати основні цінні риси функціонального призначення права. Функції права $\epsilon$ основними виразниками властивостей цивільного права, які і становлять предмет цивільно-правового регулювання.

Автори наводять погляди науковців на структуру функції права взагалі, а також на функції цивільного права, їх зміст, місце та роль у регулюванні цивільних відносин. Деякі науковці вважають, що функції цивільного права впливають на майнові відносини, немайнові відносини, а також відносини, які пов'язані з інтелектуальної власністю. Існує також думка, що функції цивільного права тільки напрями впливу на відносини. Низка вчених у функціях цивільного права бачать основні напрями впливу на майнові й особисті відносини рівноправних суб'єктів із метою розвитку суспільства та задоволення потреб громадян.

Аналізуючи погляди вчених на сутність функцій, ми бачимо, що важливим елементом цієї сутності є «напрям впливу». Саме правильно обраний законодавцем напрям впливу на суспільні відносини може відповідати на потреби суспільства та визначати потребу в позитивному праві. Ми погоджуємося 3 тими науковцями, які розглядають функції цивільного права як у статиці, так і в динаміці.

Ключові слова: відносини, функція, зміст, структура, види, регулятивна, охоронна, виховна, правозахисна, компенсаційна.

There is no single conceptual point of view on the system of basic functions of civil law in civil science. Therefore, the study of the functions of civil law is one of the most important tasks of modern civil science. Subject and method of civil law

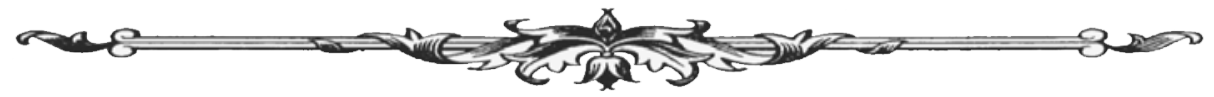


regulation, in modern conditions, can rarely be considered enough to solve the issue of branch affiliation of certain social relations. This makes the topic of civil law functions actual these days. In the article, the authors explored the system of functions of civil law, revealed the concepts, their essence and types

The value of civil law functions can be demonstrated in the development of social relations. The dynamics of the development of social relations can be the main valuable features of the functional use of law. The functions of law are the main markers of the power of civil law, which develop the subject of civil law regulation.

The authors present the scholars' views on the structure of the function of law in general, as well as the functions of civil law, their content, place and role in the regulation of civil relations. Some scientists believe that the functions of civil law affect property relations, non-property relations, as well as relationships related to intellectual property. There is a second view that according to the functions of civil law they understand only the directions of influence on relations. Various scolars see the main directions of influence on property and personal relations of equal subjects with the purpose of development of society and meeting the needs of citizens in the functions of civil law.

While analyzing the views of scientists on the essence of functions, we see that an important element of this essence is the "direction of influence". It is the right choice of the legislator to influence the social relations, which can respond to the needs of society and determine the need for a positive law. Also, we agree with those scholars who consider the functions of civil law both in statics and in dynamics.

Key words: relations, function, content, structure, types, regulatory, protective, educational, protective, compensatory.

Вступ. У правозастосовної практики суспільства велику роль відграє значущість функцій права. Функції права дозволяють нормам права впливати на суспільні відносини.

Аналізуючи правову літературу із цього питання, правозастосовну практику, можна сказати, що зміст наявних у суспільстві правових функцій відображає як соціальну роль держави, так і місце та значущість права. Практично всі науковці під функцією права розуміють або соціальне призначення права, або його вектори, форми правового впливу на суспільні відносини, або і те й інше разом.

Дослідження функцій цивільно-правових норм пояснюється тим, що розвиток і вдосконалення норм права відбуваються саме через функції права, а специфіка як предмета, так і методу цивільно-правового регулювання тісно пов’язана з особливістю функцій цивільного права. Функції права як предмет і метод характеризують певну галузь права, надають тільки їй властиві ознаки.

Постановка завдання. Виходячи із зазначеного, метою статті є визначення i розкриття поняття, сутності та видів функцій цивільного права як специфічних правових регуляторів забезпечення сталості системи цивільного права.

Результати дослідження. Слово «функція» походить від латинського терміна, яким позначалося кілька понять: «виконання», «службовий обов'язок», «сплата податків» $[1$, c. 272$]$.

Науковці в галузях права, економіки, соціології функції права найчастіше поділяють на дві основні групи видів: загальносоціальні та спеціальні.

До основних загальносоціальних функцій вони відносять політичну, культурну, виховну, економічну, інформативну, комунікативну й ін.

До спеціальних (правових) функцій, на їхню думку, належать насамперед регулятивна, охоронна, правозахисна, виховна, а також як додаткові оціночна, компенсаційна, установча й інформаційна.

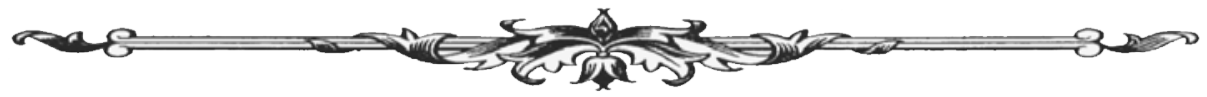


Функції права реалізуються через систему права (галузі, інститути, норми права тощо), через нормативно-правові акти, договори, прецеденти й акти застосування права, а також шляхом відповідної діяльності органів державної влади [2, с. 313].

Питання функцій права, зокрема цивільного права, постійно досліджуються вітчизнаними та закордонними вченими-юристами: Т. Боднарем, І. Дідковською, А. Довгерт, I. Жилінковою, Р. Майдаником, Н. Кузнєцовим, І. Спасибо-Фатєєвою, Р. Стефанчуком, С. Харитоновим, А. Риженковим, В. Рибаковим, П. Рабіновичем, А. Колодієм, О. Петришиною, О. Скакун, В. Гончаровим, А. Маньковським, А. Михайловим, Л. Соцуро, Ю. Тодикою й іншими.

Цивільне право як складова частина єдиної правової системи виконує особливі функції. Функції цивільного права також характеризують його місце в системі права, оскільки окремі галузі відрізняються за змістом і характером виконуваних ними функцій. Функції цивільного права визначаються специфікою предмета та методу цивільного права, а також завданнями, які стоять перед ним.

У цивілістичній літературі пропонуються різні визначення функцій цивільного права. Наприклад, функції цивільного права визначаються як зумовлені предметом і забезпечувані законодавством цілі правової галузі, певні напрями цивільно-правового випливу на особисті немайнові та майнові відносини [3, с. 18].

Схожим на наведене $\epsilon$ визначення функцій цивільного права як відповідних напрямів впливу цивільно-правових норм на врегульовані ними майнові й особисті немайнові відносини, спрямованих на досягнення поставлених перед даною галуззю права цілей і завдань [4, с. 24].

У найбільш загальному вигляді теоретики права розуміють під функцією норми права соціальне призначення правових норм або напрям правового впливу на суспільні відносини, або і те й інше разом [5, с. 167].

Можна погодитися з В. Рибаковим, який так визначає цивільно-правову функцію як «<..> зумовлений товарно-грошовою формою і завданнями держави вплив цивільно-правових норм на майнові та немайнові відносини у визначених і різних за сферою напрямах» [6, c. 13].

Як зазначає А. Риженков, структура будь-якої функції права має такі елементи: зміст функції, об’єкт функції, суб’єкт реалізації функції, а також засоби забезпечення реалізації функції.

Елементи структури функції - це те, за допомогою чого формується спосіб впливу права на суспільні відносини, вони завжди тісно пов'язані із цілями та завданнями права.

Зміст функції права - це сутність, ознаки та властивості права, спосіб впливу на суспільні відносини у визначеному напрямі. 3'ясування змісту функції права розкриває цілі та завдання цього права.

Об'єкт функції - група суспільних відносин, на які спрямований вплив функції.

До суб'єктів реалізації функції завжди відносять законодавця, органи державної влади та місцевого управління, а також правоохоронні органи.

Засоби забезпечення виконання функції визначаються рівнем розвитку економіки та цілями, які ставить держава перед суспільством і правом [7, с. 57].

Функції цивільного права мають свою специфіку, яка залежить від предмета регулювання. Відомо, що цивільне право регулює в суспільстві майнові та немайнові відносини, а також відносини, пов'язані з інтелектуальної власністю. Предмет регулювання цивільного права відрізняе його від предметів регулювання інших галузей права, у яких специфіка функцій буде інакшою.

Із вищезазначених думок учених-правознавців щодо поняття та змісту функцій цивільного права можна зробити висновок про те, що функції цивільного права $є$ певними напрямами впливу на відносини через закріплення в цивільно-правових нормах правил, виходячи зі специфіки предмета, методу та завдань, що стоять перед ним.

Отже, функції цивільного права - це основні напрями правового впливу на цивільно-правові відносини з метою їх упорядкування, виходячи зі специфіки предмета, у напрямах, визначених законодавством, регулювання, та реалізації.

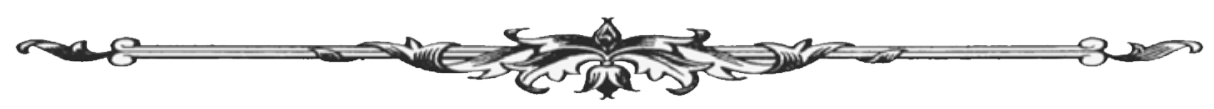


Серед правознавців немає єдиної думки щодо видів функцій цивільного права. Ще не склалося єдиного доктринального погляду на це. Такі автори, як Є. Суханов, Н. Козлова $[8$, c. 48,49$]$, до основних функцій цивільного права відносять лише регулятивну й охоронну. Інші ж пропонують виокремлювати також компенсаційну та превентивну (В. Борисова $[9$, с. 87], С. Приступа $[10$, с. 21$])$, а також попереджувально-виховну й попереджувально-стимулюючу (Р. Майданик [11, с. 131]), організаційну, компенсаційну, виховну, каральну та функцію захисту (А. Риженков) [12, с. 48; 6, с. 48], відновлювальну (Ш. Менглієв) [13, с. 14-17], функцію забезпечення моральності (В. Васильєв) [14, с. 160-163] тощо.

Традиційно в юридичній літературі до функцій цивільного права відносять: регулятивну, охоронну, компенсаційну, правозахисну, а також в окремих випадках додатково зазначають виховну (превентивну), каральну, статичну, динамічну, відновлювальну.

Спробуємо розглянути зміст функцій, які реалізуються в цивільно-правових відносинах.

Регулятивна функція цивільного права зумовлена його цілями, пов'язаними з виконанням завдань, що стоять перед цивільним правом як галуззю права, та полягає в позитивному регулюванні цивільних відносин, наданні прав і обов'язків учасникам цих відносин, встановленні правил поведінки суб'єктів цивільного права. Такі правила поведінки містяться в законах і підзаконних актах, укладених договорах і судових рішеннях. Наприклад, у ст. 759 Цивільного кодексу України зазначено, що за договором найму (оренди) наймодавець передає або зобов'язується передати наймачеві майно в користування за плату на певний строк.

Охоронна функція цивільного права спрямована на встановлення та гарантування державою заходів юридичного захисту та юридичної відповідальності, порядку їх покладання та виконання, має на меті усунення шкідливих для суспільства відносин і охорону позитивних.

Охоронний вплив здійснюється за допомогою спеціальних охоронних норм, а також регулятивних норм, спрямованих на охорону суб'єктивних прав, визначення заборон на вчинення протиправних діянь; встановлення юридичних санкцій за вчинення таких діянь; безпосереднє застосування юридичних санкцій до особи, яка вчинила правопорушення.

Охорона функція полягає в позитивному регулюванні цивільних відносин, наданні прав і обов'язків учасникам цих відносин, встановленні правил поведінки суб'єктів цивільного права.

Правозахисна (захисна) функція забезпечує застосування державою, у разі спричинення шкоди суб'єкту, правових норм впливу, ця функція спрямована на захист його суб'єктивних прав.

Якщо проаналізувати зміст охоронної та правозахисної функцій, то можна знайти деякі спільні риси. Як охоронна, так і правозахисна функції спрямовані на профілактичний ефект. Мета їх застосування - утримати суб'єкта цивільних правовідносин від порушення зобов'язань. Вони також мають єдиний спосіб здійснення, а саме можливість застосування державного примусу.

Але $\epsilon$ те, що відрізняє їх. Реалізація охоронної функції здійснюється за допомогою дотримання суб'єктами права цивільно-правових норм, які регулюють їхні правила поведінки. Правозахисна функція починає діяти з моменту виконання як форма реалізації права. Ми бачимо, що вони мають різний спосіб впливу на поведінку суб'єктів, а також різняться формами реалізації права.

Тому ми погоджуємось з О. Скакун, яка зазначає, що «охоронна і захисна функції права не дублюють одна одну, вони взаємопов'язані та витікають одна з одної, бо немає об'єктів, які б тільки охоронялися чи тільки захищалися» [16, с. 236, 237].

Компенсаційна функція у процесі реалізації забезпечує можливість відновлення порушеного цивільного права й інтересу на еквівалентній основі. Така функція $є$ специфічною та властива лише цивільному праву. На думку І. Власенко, сутність компенсаційної функції права полягає в тому, що взяті у взаємодії та єдності всі елементи і властивості права повинні бути спрямовані на компенсування фізичної, матеріальної, моральної й іншої шкоди, яку

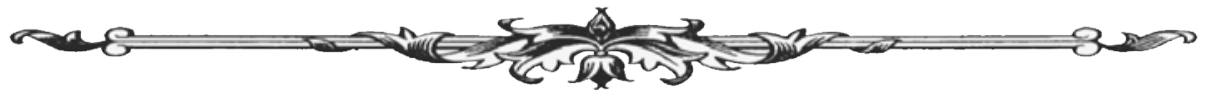


завдано як протиправними, так і правомірними діями (бездіяльністю), подіями окремим особам, колективам і організаціям [17, с. 14 ]

Виховна (превентивна) функція полягає у вихованні поваги до правопорядку, цивільних прав інших осіб, покликана забезпечити утримання учасників цивільних відносин від порушення чужих прав тощо. На думку М. Байтіна, вона не $\epsilon$ власне юридичною, а виражає загальносоціальну, так звану ідеологічну частину впливу права на поведінку людей [18, с. 9-12].

Відновлювальна функція покликана відновити порушене право або інтерес, тобто привести до початкового стану. Це зазначено в п. 4 ч. 2 ст. 16 Цивільного кодексу України «Відновлення становища, яке існувало до порушення». Відновлювання порушених прав $\epsilon$ одним з основних принципів цивільного права.

Каральна функція містить елемент покарання. У цивільних відносинах цю функція виконується, наприклад, у разі невиконання договірних зобов'язань - сплата неустойки, ст. 549 Цивільного кодексу України, або під час застосування наслідків недійсності правочинів - ч. 2 ст. 230 Цивільного кодексу України («сторона, яка застосувала обман, зобов’язана відшкодувати другій стороні збитки у подвійному розмірі та моральну шкоду, що завдані у зв'язку із вчиненням цього правочину»).

Перелік названих функцій цивільного права не має вичерпного характеру, цивільні відносини за останні рокі стали все більш різноманітними як за предметом, методом, так і за наслідками.

Висновки. Як підсумок із вищевикладеного можна зазначити, що функції цивільного права покликані спрямувати подальший розвиток цієї галузі права в умовах ринкових відносин і різноманіття форм власності. Специфіка предмета і метода цивільно-правового регулювання тісно пов'язана з особливістю цивільно-правових норм, що підкреслює значущість ролі функцій, їх взаємодія з іншими регуляторами цивільно-правових відносин.

\section{Список використаних джерел:}

1. Гриценко С. Латинська мова й основи римського права : навчальний посібник. Київ : Центр навч. літ., 2005.

2. Юридична енциклопедія : у 6-ти т. / редкол.: Ю. Шемшученко (гол. редкол.) та ін. Київ : Укр. енцикл., 2004. Т. 6.

3. Цивільне право України : підручник : у 2-х т. / В. Борисова та ін. ; за заг. ред. В. Борисової, І. Спасибо-Фатєєвої, В. Яроцького. Київ : Юрінком-Інтер, 2004. Т. 1.

4. Цивільне право України : підручник : у 2-х кн. / О. Дзера та ін. ; за ред. О. Дзери, Н. Кузнєцової. Київ : Юрінком-Інтер, 2002. Кн. 1.

5. Енгибарян Р. Теория государства и права : учебник для вузов. Москва : МГУ, 1999. 254 с.

6. Рыбаков В. Функции гражданско-правового регулирования (общетеоретические и воспитательные аспекты) : монография. Москва : Юрист, 2011. С. 13.

7. Рыженков А. Функции гражданского права: вопросы теории.

8. Суханов Е., Козлова Н. Функции гражданского права. Гражданское право : в 4-х т. : учебник для студентов вузов, обучающихся по направлению 521400 «Юриспруденция» по специальности 021100 «Юриспруденция» / В. Ем и др. ; отв. ред. Е. Суханов. 3-е изд., перераб. и доп. Т. 1 : Общая часть. Москва : Волтерс Клувер, 2008. 736 с.

9. Менглиев Ш. Восстановительные правоотношения в советском гражданском праве : учебное пособие. Душанбе, 1986. 117 с.

10. Рыженков А. Компенсационная функция гражданского права / науч. ред. В. Тархов. Саратов : Изд- во Сарат. ун-та, 1983. 95 с.

11. Хецуриани Д. Функции советского гражданского права: теоретические проблемы, понятия и системы. Тбилиси : Мецниереба, 1990. 147 с.

12. Приступа С. Функції цивільного права. Цивільне право : підручник : у 2-х т. / В. Борисова та ін. ; за ред. В. Борисової, І. Спасибо-Фатєєвої, В. Яроцького. 2-ге вид., переробл. і допов. Харьків : Право, 2014. Т. 1. 656 с.

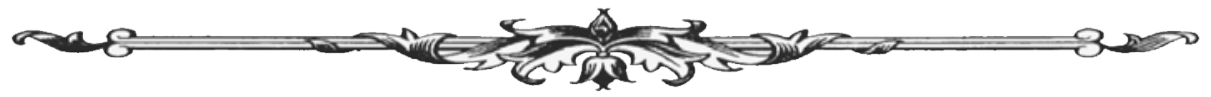


13. Майданик Р. Цивільне право : Загальна частина. Т. I : Вступ у цивільне право. Київ : Алерта, 2012. 472 с.

14.Васильев В.В. Теоретические проблемы детерминизма в системе гражданского права Российской Федерации : монография. Москва : Юнити-Дана ; Закон и право, 2015. $351 \mathrm{c}$.

15. Скакун О. Теорія права і держави : підручник. 2-ге вид. Київ : Алерта ; КНТ ; ЦУЛ, 2010. $520 \mathrm{c.}$

16. Власенко И. Компенсационная функция права (вопросы теории и практики) : автореф. дис. ... канд. юрид. наук. Нижний Новгород, 1995.

17.Байтин М. О принципах и функциях права: новые моменты. Правоведение. 2000. № 3. C. $9-12$.

ХОДИкО Ю. Є., кандидат юридичних наук, доцент кафедри цивільного права № 1 (Національний юридичний університет імені Ярослава Мудрого)

\section{ЩОДО РОЗУМІННЯ СУТНОСТІ РЕЗУЛЬТАТУ РОБІТ ТА ПОСЛУГ ЯК ОБ'ЄКТІВ ЦИВІЛЬНИХ ПРАВОВІДНОСИН}

У статті автором розглядається питання сутності результату робіт та послуг як об’єктів цивільних правовідносин. Дослідження сутності вказаних об' єктів надає можливість здійснити формування їх ефективного цивільно-правового режиму.

Вказується, що результат роботи та послуга як об'єкти цивільних правовідносин являють собою результат певної діяльності особи поряд з такими об'єктами, як речі, що створені людиною та результатами інтелектуальної творчої діяльності людини (широке розуміння сутності результату робіт). Сформульований критерій, що дає можливість відмежувати результат робіт як об'єкт цивільних правовідносин від інших схожих за своєю сутністю об'єктів.

Здійснюється співвідношення результату робіт з роботою. Аналізується питання матеріальності та нематеріальності результату діяльності особи, критерії їх визначення. Приділено увагу питанню співвідношення такого результату робіт, який створює річ, змінює іiї властивості, та такого, що втілюється в речі як матеріальному носії (об'єктивується), що має значення для кваліфікації певного результату як об'єкта цивільного правовідношення.

У статті проаналізовано дві найбільш поширені концепції сутності послуги як об'єкта цивільних правовідносин - об'єкта-дії та об'єкта-корисного ефекту. Автором визначено критерії послуги як об'єкта, що сформувалися сьогодні в судовій практиці на основі положень чинного цивільного законодавства та наукових досліджень.

Виділяються особливості результату робіт та послуг як об'єктів цивільних правовідносин, що дають можливість відмежувати вказані об'єкти один від одного. Автором доводиться, що результат робіт та послуга як об'єкти цивіль-

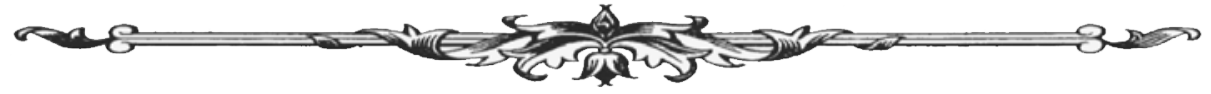

